\title{
Is cobalamin deficiency associated with increased risk of all subtypes of postoperative delirium?
}

This article was published in the following Dove Press journal:

Neuropsychiatric Disease and Treatment

16 August 2016

Number of times this article has been viewed

\section{Li-Kai Wang' \\ Kuo-Mao Lan ${ }^{1,2}$ \\ Yao-Tsung Lin ${ }^{1,2}$ \\ Jen-Yin Chen ${ }^{1,3}$}

'Department of Anesthesiology, Chi Mei Medical Center, Tainan, ${ }^{2}$ Department of Food Science and Applied Biotechnology, National Chung Hsing University, Taichung, ${ }^{3}$ Department of the Senior Citizen Service Management, Chia Nan University of Pharmacy and Science, Tainan, Taiwan
Correspondence: Jen-Yin Chen Department of Anesthesiology, Chi Mei Medical Center, No 90I, ZhongHua Road, Yongkan District, Tainan City, Taiwan

$\mathrm{Tel}+886628128 \mathrm{II}$

Fax +88662512436

Email chenjenyin@gmail.com

\section{Dear editor}

In a recent paper, Sevuk et al used the single-hospital-based database to investigate whether cobalamin (vitamin B12) deficiency increased the risk of postoperative delirium in patients aged $>60$ years undergoing cardiac surgery with cardiopulmonary bypass. ${ }^{1}$ In this retrospective study, the incidence of postoperative delirium in 100 patients with cobalamin deficiency was compared to 100 controls without cobalamin deficiency. Because the incidence of postoperative delirium in patients with cobalamin deficiency was significantly higher than that in the control group $(P=0.017)$, the authors concluded that cobalamin deficiency may be associated with increased risk of delirium in elderly patients undergoing cardiac surgery. This article has drawn the attention of anesthesiologists who are involved in prevention and treatment of postoperative delirium.

Apparently, the conclusion raises a plausible defect when all patients developing delirium were considered as one group. Delirium is a clinical diagnosis with a wide range of neuropsychiatric manifestations. The pathophysiology of delirium is not fully understood. Delirium is classified as hyperactive, hypoactive, or mixed forms. ${ }^{2}$ Etiologic diagnosis of the hyperactive and hypoactive subtypes of delirium may be different. ${ }^{3}$ Nutritional status has been suggested to play a role in predisposing or directly causing this acute cerebral dysfunction. ${ }^{4}$ A previous study reported that vitamin B12 supplementation for 40 weeks reduced delirium in demented patients aged over 60 years with low serum vitamin B12 $(<200 \mathrm{pmol} / \mathrm{L}) .{ }^{5}$ In the model, a reasonable result was demonstrated because delirium is often reversible when the underlying cause of delirium is treated. ${ }^{4}$ It is well-known that patients with cobalamin deficiency may develop a wide range of neuropsychiatric manifestations such as restless, aggressiveness, delirium, cognitive impairment, depression, hallucination, and mania. Based on the literal reports, agitated manifestations seem to be more likely. ${ }^{6-8}$ Subtypes of delirium may be explained by different pathophysiologic mechanisms. Subgroup analysis by classifying delirious patients into hyperactive and hypoactive subtypes may be conducted to give the readers more information.

The cause of delirium is often multifactorial. ${ }^{4}$ In patients with cobalamin deficiency, differences between delirium and nondelirium patients should be compared to identify additional risk factors such as chronic obstructive pulmonary disease and diabetes mellitus to help patients. ${ }^{910}$ Furthermore, a binary or trinary model in patients with cobalamin deficiency ${ }^{11}$ may be performed to assess the association between serum cobalamin levels and the incidence of delirium to support the conclusion with biological plausibility. ${ }^{4}$ 


\section{Disclosure}

The authors report no conflicts of interest in this communication.

\section{References}

1. Sevuk U, Baysal E, Ay N, et al. Relationship between cobalamin deficiency and delirium in elderly patients undergoing cardiac surgery. Neuropsychiatr Dis Treat. 2015;11:2033-2039.

2. Stagno D, Gibson C, Breitbart W. The delirium subtypes: a review of prevalence, phenomenology, pathophysiology, and treatment response. Palliat Support Care. 2004;2(2):171-179.

3. Kumar A, Bakhla AK, Gupta S, Raju BM, Prasad A. Etiologic and cognitive differences in hyperactive and hypoactive delirium. Prim Care Companion CNS Disord. 2015;17(6).

4. Sanford AM, Flaherty JH. Do nutrients play a role in delirium? Curr Opin Clin Nutr Metab Care. 2014;17(1):45-50.

5. Kwok T, Lee J, Lam L, Woo J. Vitamin B(12) supplementation did not improve cognition but reduced delirium in demented patients with vitamin B(12) deficiency. Arch Gerontol Geriatr. 2008;46(3):273-282.
6. Zhang Q, Lv XY, Yang YM. Megaloblastic anemia with hypotension and transient delirium as the primary symptoms: report of a case. Int $J$ Clin Exp Med. 2015;8(10):18879-18883.

7. Lachner C, Steinle NI, Regenold WT. The neuropsychiatry of vitamin B12 deficiency in elderly patients. J Neuropsychiatry Clin Neurosci. 2012;24(1):5-15.

8. Kibirige D, Wekesa C, Kaddu-Mukasa M, Waiswa M. Vitamin B12 deficiency presenting as an acute confusional state: a case report and review of literature. Afr Health Sci. 2013;13(3):850-852.

9. Fimognari FL, Loffredo L, Di Simone S, et al. Hyperhomocysteinaemia and poor vitamin B status in chronic obstructive pulmonary disease. Nutr Metab Cardiovasc Dis. 2009;19(9):654-659.

10. Chapman LE, Darling AL, Brown JE. Association between metformin and vitamin B deficiency in patients with type 2 diabetes: a systematic review and meta-analysis. Diabetes Metab. Epub 2016 Apr 26.

11. Chen JY, Chu CC, Lin YS, So EC, Shieh JP, Hu ML. Nutrient deficiencies as a risk factor in Taiwanese patients with postherpetic neuralgia. Br J Nutr. 2011;106(5):700-707. 


\section{Authors' reply \\ Utkan Sevuk' \\ Erkan Baysal ${ }^{2}$ \\ Nurettin $\mathrm{Ay}^{3}$ \\ Yakup Altas ${ }^{2}$ \\ Rojhat Altindag ${ }^{2}$ \\ Baris Yaylak ${ }^{2}$ \\ Vahhac Alp ${ }^{3}$ \\ Ertan Demirtas ${ }^{4}$ \\ 'Department of Cardiovascular Surgery, Diyarbakir Gazi Yasargil Education and Research Hospital, Diyarbakir, ${ }^{2}$ Department of Cardiology, Diyarbakir Gazi Yasargil Education and Research Hospital, Diyarbakir, ${ }^{3}$ Department of General Surgery, Diyarbakir Gazi Yasargil Education and Research Hospital, Diyarbakir, ${ }^{4}$ Department of Cardiovascular Surgery, Liv Hospital, Ankara, Turkey}

Correspondence: Utkan Sevuk

Diyarbakir Gazi Yașargil Egitim ve Arastirma Hastanesi, Kalp ve Damar Cerrahisi Klinigi, 3 kat, Uckuyular, Diyarbakir 21010, Turkey

Tel +90505 5307095

Email utkansevuk@gmail.com

\section{Dear editor}

We read with great interest the letter to the editor written regarding our article 'Relationship between cobalamin deficiency and delirium in elderly patients undergoing cardiac surgery', and appreciate the opportunity to respond to the letter. ${ }^{1}$

In our study, we examined the relationship between cobalamin deficiency and delirium in elderly ( $>65$ years old) patients undergoing coronary artery bypass grafting surgery. Multivariate analysis demonstrated that cobalamin deficiency was independently associated with postoperative delirium in patients undergoing coronary artery bypass grafting. We agree that subgroup analysis regarding the types of delirium would give more information to the readers. Although, subgroup analysis by classifying delirious patients into hyperactive and hypoactive subtypes could be conducted in our study, this analysis would have a lower statistical power. Based on previous reports, hyperactive delirium rate is higher in patients with cobalamin deficiency. ${ }^{2-4}$ However, delirium after cardiac surgery with cardiopulmonary bypass may be explained by different pathophysiologic mechanisms.

We believe that the association between cobalamin deficiency and the type of delirium can be examined in another study with a larger sample size.

\section{Disclosure}

The authors report no conflicts of interest in this communication.

\section{References}

1. Sevuk U, Baysal E, Ay N, et al. Relationship between cobalamin deficiency and delirium in elderly patients undergoing cardiac surgery. Neuropsychiatr Dis Treat. 2015;11:2033-2039.

2. Zhang Q, Lv XY, Yang YM. Megaloblastic anemia with hypotension and transient delirium as the primary symptoms: report of a case. Int J Clin Exp Med. 2015;8(10):18879-18883.

3. Lachner C, Steinle NI, Regenold WT. The neuropsychiatry of vitamin B12 deficiency in elderly patients. $J$ Neuropsychiatry Clin Neurosci. 2012;24(1):5-15.

4. Kibirige D, Wekesa C, Kaddu-Mukasa M, Waiswa M. Vitamin B12 deficiency presenting as an acute confusional state: a case report and review of literature. Afr Health Sci. 2013;13(3):850-852.

Dove Medical Press encourages responsible, free and frank academic debate. The content of the Neuropsychiatric Disease and Treatment 'letters to the editor' section does not necessarily represent the views of Dove Medical Press, its officers, agents, employees, related entities or the Neuropsychiatric Disease and Treatment editors. While all reasonable steps have been taken to confirm the content of each letter, Dove Medical Press accepts no liability in respect of the content of any letter, nor is it responsible for the content and accuracy of any letter to the editor.

\section{Publish your work in this journal}

Neuropsychiatric Disease and Treatment is an international, peerreviewed journal of clinical therapeutics and pharmacology focusing on concise rapid reporting of clinical or pre-clinical studies on a range of neuropsychiatric and neurological disorders. This journal is indexed on PubMed Central, the 'PsycINFO' database and CAS, and is the official journal of The International Neuropsychiatric Association (INA). The manuscript management system is completely online and includes a very quick and fair peer-review system, which is all easy to use. Visit http://www.dovepress.com/testimonials.php to read real quotes from published authors. 